\title{
Tuberculosis and Coronavirus Disease 2019 (COVID-19) from A Clinical Perspective: A Systematic Review
}

\author{
Klinik Perspektiften Tüberküloz ve 2019 Koronavirüs Hastalığı (COVID-19): \\ Sistematik Bir Inceleme
}

\author{
Tri Hari Irfani $\odot$, Reynold Siburian $\odot$, Riska Nabila $\odot$, Tungki Pratama Umar $\odot$
}

Ethics Committee Approval: Not Applicable.

Conflict of interest: The authors declare that they have no conflict of interest. Funding: None.

Informed Consent: Not Applicable.
Cite as: Irfani TH, Siburian R, Nabila R, Umar TP. Tuberculosis and coronavirus disease 2019 (COVID-19) from a clinical perspective: A Systematic Review. Medeni Med J. 2020;35:338-43.

\begin{abstract}
The aim of this review is to examine the effects of COVID-19 on Tuberculosis (TB) management and to highlight evidence of the extent of TB and COVID-19 co-infection. Current findings on TB and COVID-19 have been identified using six databases: Pubmed, Science Direct, Pubmed Central, MedXRiv, Wiley, and Google Scholar. This search in literature was conducted up to 8 May 2020. We included five studies that met the selection criteria. These selected studies have been performed in regions having various demographic characteristics including developed and developing countries, mainly China. The total number of participants in each study ranged from 24 to 203. The case fatality rate of patients with TB and COVID-19 co-infection was found to be high (6/49; 12.3 percent) while a combined diagnosis of TB and COVID-19 was found in 9/49 patients. This condition is linked to several complications, manifested as the need for ex novo oxygen supply, pneumothorax, and extreme hypoxia. Researches on BCG vaccination have shown that countries without vaccination policy are more likely to be seriously affected than those with $B C G$ vaccination programs. COVID-19 infection in patients with $T B$ or the lack of sufficient $B C G$ vaccination may be associated with higher detrimental consequences, including mortality.
\end{abstract}

Keywords: BCG vaccine, COVID-19, tuberculosis

öz

Bu incelemenin amacı, COVID-19'un Tüberkülöz (TB) yönetimi üzerindeki etkilerini incelemek ve TB ile COVID-19 ko-enfeksiyonunun kapsamına ilişkin kanıtları vurgulamaktır. TB ve COVID-19 ile ilgili mevcut bulgular altı veri tabanı kullanılarak tanımlanmıştır: Pubmed, Science Direct, Pubmed Central, MedXRiv, Wiley ve Google Scholar. Bu kaynaklardan 8 Mayıs 2020 tarihine kadar literatür taraması yapılmıştır. Seçim kriterlerine uyan beş çalışma seçilmiştir. Bu seçilmiş çalışmalar, başta Çin olmak üzere, gelişmiş ve gelişmekte olan ülkeler dahil olmak üzere çeşitli demografik özelliklere sahip bölgelerde gerçekleştirilmiştir. Çalışmalardaki katılımcı sayıları ise 24 ile 203 arasında değişmiştir. Kombine TB ve COVID-19 tanısı 9/49 oranında hastada bulunurken, TB ve COVID-19 ko-enfeksiyonu olan vakaların ölüm oranı yüksek (6/49; \%12,3) bulunmuştur. Bu durum ex novo oksijen kaynağı ihtiyacı, pnömotoraks ve așırı hipoksi olarak ortaya çıkan çeșitli komplikasyonlarla bağlantılıdır. BCG aşılaması üzerine yapılan araştırmalar, aşılama politikası olmayan ülkelerin etkilenme olasılığının așılama programları olan ülkelere göre ciddi șekilde daha yüksek olduğunu göstermiştir. TB hastalarında COVID-19 enfeksiyonu bulunması veya yeterli BCG aşısının olmaması, mortalite dahil daha yüksek zararlı sonuçlarla ilişkili olabilir.

Anahtar kelimeler: BCG aşısı, COVID-19, tüberküloz
Received: 17 August 2020

Accepted: 27 September 2020

Online First: 25 December 2020

Corresponding Author: T. H. Irfani

ORCID: 0000-0001-9098-8865

Universitas Sriwijaya, Faculty of Medicine,

Department of Public Health and Community Medicine,

Palembang, Indonesia

trihariirfani@fk.unsri.ac.id

R. Siburian ORCID: 0000-0003-0317-4113

R. Nabila

ORCID: 0000-0002-0884-764X

T. P. Umar

ORCID: 0000-0001-6975-8096

Universitas Sriwijaya,

Faculty of Medicine,

Medical Profession Student,

Palembang, Indonesia 


\section{INTRODUCTION}

The World Health Organization (WHO) confirmed a new form of pneumonia with an unclear cause on 31 December 2019 in Wuhan, China. After the first outbreak, the disease has spread exponentially across the globe. The rise made it possible for the WHO to issue a statement claiming that the epidemic is a public health emergency of international concern. Since February 12, 2020, COVID-19 (coronavirus disease 2019) has been used as the official name of the disease replacing 2019 n-CoV (coronavirus novel 2019). SARSCoV-2 is known as the pathogen responsible for this infection ${ }^{1,2}$.

COVID-19 has a person-to-person transmission that is mostly induced by droplets and close contact, distinct from other respiratory pathogens such as tuberculosis (TB) that spreads airborne. Fomites are major sources of the infection and SARS-CoV-2 can survive in the open environment for three hours. Virus transmitted by the infected person's droplets can stick to the surface and cause transmission if the individual touches on the contaminated surface; and also touches on the eye, nose, and mouth without adequate hygiene precautions ${ }^{1}$.

Major clinical symptoms of COVID-19 include fever, cough, and trouble breathing. Less common symptoms may include fatigue, myalgia, and gastrointestinal symptoms such as diarrhea. It is believed that SARS-CoV-2 has been transmitted first from animals to humans, and eventually among human beings. Asymptomatic transmission can occur with COVID-19. The incubation period of the disease is from one to 14 days, with an average of three to seven days ${ }^{4}$.

TB is an ancient disease that has been described as a major problem worldwide. One third portion of the world's population (about 1.7 billion) have been afflicted with Mycobacterium tuberculosis ${ }^{5}$. By $2018,87 \%$ of new TB cases occurred in the 30 high TB burden countries. Constituting two-thirds of the new cases of TB, there are eight major contributors, including India, China, Indonesia, the Philippines, Pakistan, Nigeria, Bangladesh, and South Africa. Southeast Asia, followed by Africa and the Western Pacific, are the key geographical areas impacted by this situation ${ }^{6}$.

According to the study model, if the COVID-19 pandemic triggers a 3-month decrease in the TB detection rate (a reasonable prediction given the TB detection issue in many countries) there would be a rise of 13 percent in TB deaths, leading to the TB mortality rate like five years ago ${ }^{7}$. This calculation is very conservative and does not take into account certain impacts of this pandemic on the incidence of TB.

Therefore, we conduct a systematic review to assess the evidence of TB and COVID-19, especially from clinical perspective. This study may help to examine the impact of COVID-19 on TB management and to highlight the evidence on severity of co-infection with TB and COVID-19.

\section{MATERIAL and METHODS}

We adopted the Preferred Reporting Items for Systematic Reviews and Meta-Analysis (PRISMA) criteria for the preparation of manuscripts. The inclusion criteria comprised of researches relating to our goal (they must be explanatory about TB or BCG, and its association with COVID-19). Studies must be conducted in English and include observational studies (cross-sectional, case-control, and cohort design). The full text of the studies must also be available. The exclusion parameters related to the characteristics of studies were also determined. Articles, thoughts, critiques, editorials, case reports and case series, observational research, and those with an experimental design were not included in our review. We have two objectives: (i) to evaluate the prevalence of TB in COVID-19 patients; (ii) to assess the effect of TB on the clinical course of COVID-19. 
The databases of MEDLINE/PubMed, Pubmed Central (PMC), Science Direct, Wiley, MedXriv, and Google Scholar were scanned using the keywords given in Table I. Then selected studies were reviewed for their titles and abstracts by reviewers and balanced with inclusion and exclusion criteria. Literature search was conducted up to May 8, 2020. After screening, the qualifying studies have been downloaded and the full texts were further read by reviewers. Thereafter, they reached a consensus on which studies would be included for review.

\section{RESULTS}

Our search strategies have listed a total of 1914 potentially relevant articles. We recognized 11 papers after screening by their titles and abstracts. We eventually agreed that five studies should be included in our systematic review after a careful reading of the full text and removing studies that did not apply to our goal. There is only one article referring to our second objective. Due to the lack of available TB literature and COVID-19, we decided to include BCG studies in our analysis because they are related to TB and might potentially disclose the effect of TB on COVID-19. The flow of our sample collection is described following the PRISMA Statement (Figure 1).

Table 2 summarizes the features of six studies arranged by the first author's names. Three studies were of cross-sectional design, two with retrospective cohort design, and one study used casecontrol design. Two of the studies were conducted in China, one from US (through the Internet source), one from Italy, and the last one was a multi-centered study. Total number of participants in each study ranged from 24 to 203.

One research revealed that the co-infection of TB and COVID-19 resulted in a high case fatal-

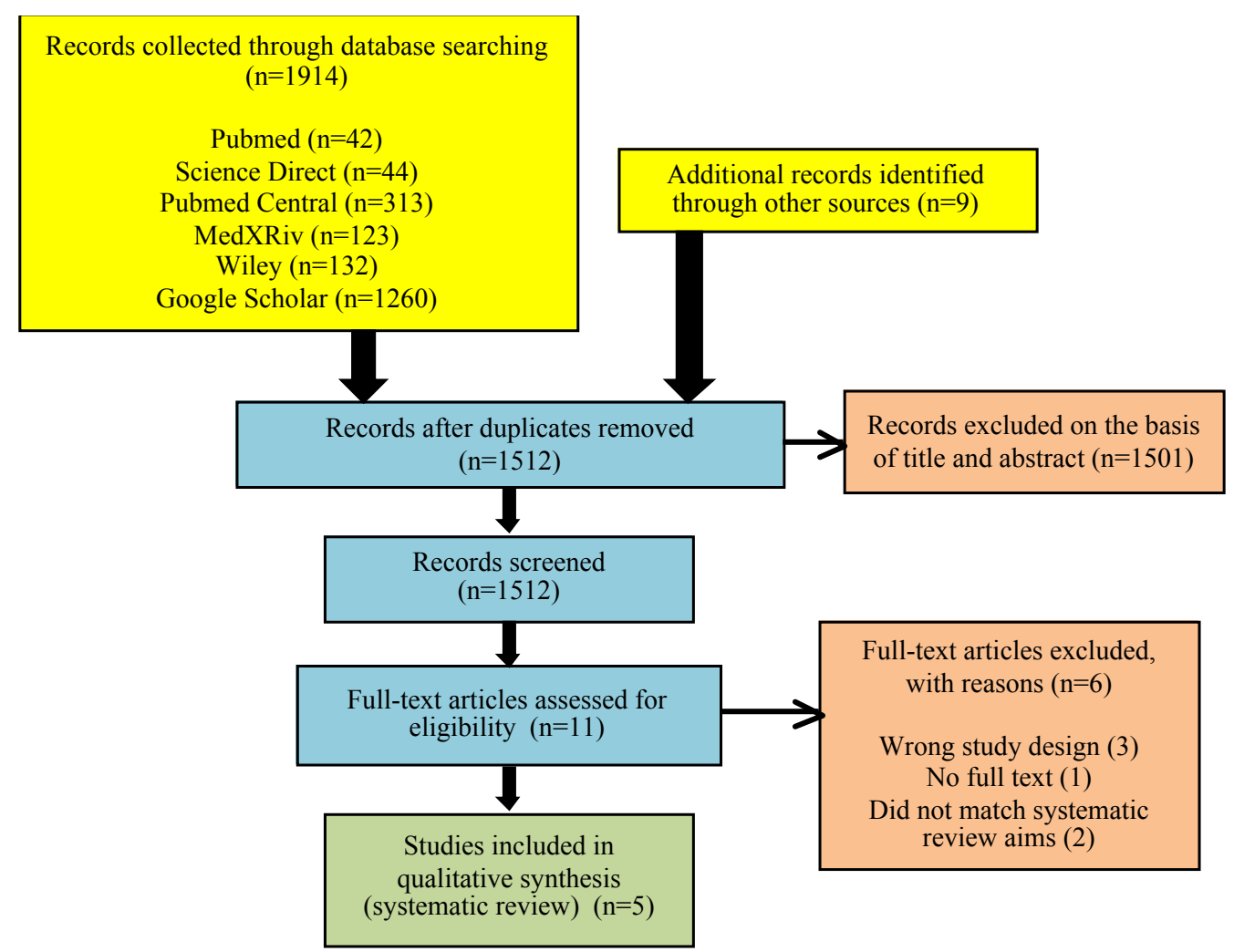

Figure 1. Diagram for the identification and exclusion of study in systematic review process. 
Table I. Terminology used in search queries.

\begin{tabular}{|c|c|c|c|}
\hline Location & Terminology & Hits & Selected \\
\hline Pubmed & [tuberculosis OR TB] AND [SARS-Cov-2] & 42 & 0 \\
\hline Sciencedirect & [tuberculosis OR TB] AND SARS-Cov-2] AND characteristic & 44 & 0 \\
\hline PMC & [tuberculosis OR TB] AND SARS-Cov-2] & 313 & 2 \\
\hline MedXriv & [tuberculosis OR TB] AND SARS-Cov-2] AND clinical characteristic & 123 & 1 \\
\hline Wiley & [tuberculosis OR TB] AND SARS-Cov-2] AND clinical characteristic & 132 & 0 \\
\hline Google Scholar & $\begin{array}{l}\text { ["tuberculosis" OR TB] AND SARS-Cov-2] AND clinical characteristic AND Risk factor } \\
\text { AND Clinical features }\end{array}$ & 1260 & 3 \\
\hline
\end{tabular}

Table 2. Summary and important results of five included studies.

\begin{tabular}{|c|c|c|c|c|c|c|c|}
\hline Studies & $\begin{array}{l}\text { Sample } \\
\text { size }\end{array}$ & Country & $\begin{array}{c}\text { Age } \\
\text { range }\end{array}$ & Gender & $\begin{array}{c}\text { Data } \\
\text { Collection }\end{array}$ & $\begin{array}{l}\text { Study } \\
\text { design }\end{array}$ & Results \\
\hline Tadolini et $\mathrm{al}^{8}$ & $n=49$ & $\begin{array}{l}\text { Belgium, } \\
\text { Brazil, } \\
\text { France, } \\
\text { Italy, Russia, } \\
\text { Singapore, } \\
\text { Spain, Swit- } \\
\text { zerland }\end{array}$ & 28.0-63.0 & $\begin{array}{l}\text { Male and } \\
\text { Female }\end{array}$ & $\begin{array}{l}\text { Medical } \\
\text { records }\end{array}$ & $\begin{array}{l}\text { Retrospective } \\
\text { cohort } \\
\text { Cross } \\
\text { sectional } \\
\text { Case control } \\
\text { Retrospective } \\
\text { cohort } \\
\text { Ecological } \\
\text { study }\end{array}$ & $\begin{array}{l}\text { There were high case fatality rate on TB patient } \\
(5 / 49,10,2 \%) .5 / 6 \text { were }>60 \text { years old and all of } \\
\text { them had } \geq \text { comorbidities ( } 4 \text { COPD; } 1 \text { HIV coinfec- } \\
\text { tion plus liver and kidney diseases, hypertension } \\
\text { and cancer in different combination) } \\
\text { Simultaneous diagnosis of TB and COVID- } 19 \text { was } \\
\text { found in } 9 / 49 \text { patients) } \\
\text { Protective effects of BCG (bacillus Calmette- } \\
\text { Guérin) vaccination is inconclusive }\end{array}$ \\
\hline Stochino et $\mathrm{al}^{9}$ & $n=24$ & Italy & $27-46$ & $\begin{array}{l}\text { Male and } \\
\text { Female }\end{array}$ & $\begin{array}{l}\text { Medical } \\
\text { records } \\
\text { and } \\
\text { primary } \\
\text { clinical } \\
\text { data }\end{array}$ & & $\begin{array}{l}\text { Among } 24 \text { patients diagnosed with active TB, } 19 \\
\text { patients had COVID-19. During hospitalization, } \\
\text { three patients required ex novo oxygen supply } \\
\text { due to low saturation, among them two had res- } \\
\text { piratory complications (pneumothorax) and one } \\
\text { elderly patients with severe pulmonary TB deve- } \\
\text { loped severe hypoxia }\end{array}$ \\
\hline Chen et $\mathrm{al}^{10}$ & $n=36$ & China & $25-79$ & $\begin{array}{l}\text { Male and } \\
\text { Female }\end{array}$ & $\begin{array}{l}\text { Medical } \\
\text { records }\end{array}$ & & $\begin{array}{l}\text { TB infection is linked with disease severity }(78 \% \\
\text { of critical cases vs } 22 \% \text { of mild/moderate cases, } \\
\text { p value }=0,049) \text {. TB infection is also found more } \\
\text { common than other comorbidities }\end{array}$ \\
\hline Chen et $\mathrm{al}^{20}$ & $n=203$ & China & $41-68$ & $\begin{array}{l}\text { Male and } \\
\text { Female }\end{array}$ & $\begin{array}{l}\text { Medical } \\
\text { records }\end{array}$ & & $\begin{array}{l}\text { TB was present in } 4 \text { patients out of } 203 \text { patients. } \\
\text { one patient diagnosed with TB died after admis- } \\
\text { sion. }\end{array}$ \\
\hline Miller et al $^{11}$ & $\begin{array}{l}\mathrm{n}=60 \\
\text { countries } \\
\text { (BCG World } \\
\text { Atlas) }\end{array}$ & $\begin{array}{l}\text { United } \\
\text { States of } \\
\text { America }\end{array}$ & $\mathrm{N} / \mathrm{A}$ & $\mathrm{N} / \mathrm{A}$ & $\begin{array}{l}\text { BCG World } \\
\text { Atlas and } \\
\text { Google } \\
\text { COVID-19 } \\
\text { Map }\end{array}$ & & $\begin{array}{l}\text { Countries without BCG policy is more severely } \\
\text { affected compared to countries with BCG vacci- } \\
\text { nation policy }\end{array}$ \\
\hline
\end{tabular}

ity rate $(10.2 \%)$, in addition to some concurrent findings for diagnosis of TB and COVID-19 in 9/49 patients $^{8}$. Another research found a higher proportion of joint TB-COVID-19 infection (19/24 patients) ${ }^{9}$ which was also linked to higher number of complications in these patients ${ }^{10}$. In a country with a wide BCG implementation, our quest for BCG vaccination found that it was correlated with a milder COVID-19 event ${ }^{11}$.

\section{DISCUSSION}

\section{Co-infection of TB and SARS-CoV-2}

COVID-19 pandemic has a major effect on the prevalence of TB in healthcare facilities. Access to diagnostic tools may decrease because of limited human and material resources and social stigma attached to TB patients due to cough as a sign. This stigma has always existed for TB but has 
worsened as a result of the COVID-19 pandemic, and it may lead individuals to conceal their condition from others and to postpone visits to health facilities ${ }^{12}$. The World Health Organization has estimated that about one third of the people living with TB are now undiagnosed, untreated, and underreported. COVID-19 pandemic may increase the number of "missing" people and become a major source of transmission that lead to high morbidity and mortality ${ }^{13}$.

While SARS-CoV-2 pathophysiology has not yet been completely understood, the virus appears to have the same pathophysiology as SARS-CoV-1. Strong evidence of SARS-CoV-2 infection can cause severe inflammation by increasing expressions of cytokines such as interleukin-1 $\beta$ (IL-1 $\beta$ ), interferon- $\Delta$ (IFN- $\Delta$ ), tumor necrosis factor-5-007 (TNF-5-007), interleukin-2 (IL-2), interleukin-4 (IL-4), and interleukin-10 (IL-10) associated with an increase in the severity of the disease due to the cytokine storm ${ }^{14}$.

Since SARS-CoV-2 was first detected in December 2019, there is very little research to determine TB co-infection. Nevertheless, it was found from the available data that the TB status played a significant part in progressive severe acute respiratory syndrome coronavirus 2 (SARS-CoV-2). The incidence of TB and COVID-19 coinfection was found to be $0.45 \%$ in India on January 21, 2020. According to these results, TB may increase the risk of death for COVID-19 (2.27\% for non-TB vs $100 \%$ for TB $)^{15}$. A study in China also found that TB is the most prevalent coinfection as opposed to other comorbid conditions such as hypertension, coronary artery disease or COPD. It means that TB is a common risk factor for infection with SARSCoV-2. The research also showed that co-infection of TB would lead to a faster development of the disease, three days earlier in comparison to a non-TB patient ${ }^{10}$.

Treatment of patients diagnosed with TB can also be affected, particularly in drug-resistant TB due to issues in medication manufacturing and transport, lack of nutritional and mental support, inadequate access to healthcare facilities, and insufficient treatment of drug reactions and comorbid diseases such as HIV, diabetes, and cancer $^{16}$. In addition, treatment of comorbid diseases can have a major effect on the progression of latent TB to active TB. Preventive measures against TB among populations will lose their vigor due to the allocation of healthcare services to COVID-19 patients, and consequently non-emergency visits to healthcare facilities are not recommended ${ }^{16}$. This is particularly worrisome because TB transmission to household members may increase with COVID19 , and also by higher exposure to TB for the patient family during quarantine period ${ }^{17,18}$.

\section{BCG Vaccine and SARS-CoV-2}

Vaccination is the most effective way to avoid illness caused by pathogens such as bacteria or viruses. After the discovery of SARS, several attempts have been made to find an effective vaccine to prevent the occurrence of the disease. Several vaccine ideas have been created, such as inactivated or live-attenuated, DNA-based vaccines, recombinant proteins, virus-like particles, etc. but none has been accepted. Recent research has shown that the SARS-CoV-2 genome is $80 \%$ similar to SARS-CoV-1 and $50 \%$ similar to MERS$\mathrm{CoV}$, therefore studies on the safety of the SARSCoV-1 immune response could be helpful in developing the SARS-CoV-2 vaccine ${ }^{11,19}$.

The TB vaccine is also one of the vaccines considered to prevent COVID-19 since no approved vaccine has yet been developed. The TB vaccine has been used widely and BCG-vaccinated neonates have been shown to have a threefold lower mortality rate compared to those who did not. Recent studies have shown an inverse association between BCG vaccination and the incidence and mortality rate of COVID-19. BCG has shown to help avoid SARS-CoV-2 via an innate immune response that is beneficial to respiratory viruses similar to SARS-CoV-2 ${ }^{11,19}$. 
Our analysis has a range of limitations. First, several areas such as Africa and Australia, have not entered our quest area. It may be because published literature from these regions is not included in the five search engines that we used. Potential studies should provide a source of literature for local areas. Second, we have not been just looking for TB, we have also used BCG, trying to scan as much literature as possible, but related literature is still sparse, and the findings are only a few. Third, the recovered papers have a small number of samples, making it difficult to make generalizations.

This analysis also has a range of strengths. In the first instance, this research has been performed in both developing and developed countries. Second, it relates to the broad characteristics of the clinical aspects of TB and COVID-19 patients.

\section{Conclusion}

While the data are sparse, TB could be one of the risk factors for a rise in the mortality rate of COVID-19. In one study, TB is shown to be more severe than other comorbid medications such as hypertension, coronary artery disease, and COPD. TB can be a common risk factor for infection with SARS-CoV-2. Further research on the inter-relation between TB and SARS-CoV-2 infection with a more diverse demographics is required to boost global coverage to draw a solid conclusion on this phenomenon.

\section{REFERENCES}

1. Rothan HA, Byrareddy SN. The epidemiology and pathogenesis of coronavirus disease (COVID-19) outbreak. J Autoimmun. 2020;109:102433. [CrossRef]

2. Carlos WG, Cruz CSD, Cao B, Pasnick S, Jamil S. Novel Wuhan (2019-NCoV) coronavirus. Am J Respir Crit Care Med. 2020;201:P7-8. [CrossRef]

3. Asadi L, Tabatabaei RS, Safinejad H, Mohammadi M. New Corona Virus (COVID-19) Management in Pregnancy and Childbirth. Arch Clin Infect Dis. 2020;15(COVID-19): e102938. [CrossRef]

4. Donders F, Lonnée-Hoffmann R, Tsiakalos A, et al. ISIDOG recommendations concerning COVID-19 and pregnancy. Diagnostics. 2020;10:1-23. [CrossRef]

5. World Health Organization. Global tuberculosis report
2019 [Internet]. Geneva: World Health Organization; 2019 [cited 2020 Jul 27]. 6 p. Available from: https:// apps.who.int/iris/bitstream/handle/10665/329368/978 9241565714-eng.pdf?ua=1

6. World Health Organization. Tuberculosis [Internet]. 2020 [cited 2020 Jul 27]. Available from: https://www.who. int/news-room/fact-sheets/detail/tuberculosis

7. Marimuthu Y, Nagappa B, Sharma N, Basu S, Chopra KK. COVID-19 and tuberculosis: A mathematical model based forecasting in Delhi, India. Indian J Tuberc. 2020;67:17781. [CrossRef]

8. Tadolini M, Codecasa LR, Blanc F, et al. Active tuberculosis, sequelae and COVID-19 coinfection: first cohort of 49 cases. Eur Respir J. 2020;56:2001398. [CrossRef]

9. Stochino C, Villa S, Zucchi P, Parravicini P, Gori A, Carlo M. Clinical characteristics of COVID-19 and active tuberculosis co-infection in an Italian reference hospital Clinical characteristics of COVID-19 and active tuberculosis co-infection in an Italian reference hospital. Eur Respir J. 2020;2001708. [CrossRef]

10. Chen Y, Wang Y, Fleming J, et al. Active or latent tuberculosis increases susceptibility to COVID-19 and disease severity. medRxiv. 2020;1-15. [CrossRef]

11. Miller A, Reandelar MJ, Fasciglione K, Roumenova V, Li Y, Otazu GH. Correlation between universal BCG vaccination policy and reduced morbidity and mortality for COVID-19: an epidemiological study. MedRxiv. 2020; 1-9. [CrossRef]

12. Bonadonna LV, Saunders MJ, Zegarra R et al. Why wait? The social determinants underlying tuberculosis diagnostic delay. PLoS One. 2017;12(e0185018). [CrossRef]

13. Datta S, Evans C. Healthy survival after tuberculosis. Lancet Infect Dis. 2019;19:1045-7. [CrossRef]

14. Guan WJ, Ni ZY, Hu Y, et.al. Clinical characteristics of coronavirus disease 2019 in China. N Engl J Med. 2020;382:1708-20. [CrossRef]

15. Yasri S W V. Tuberculosis and novel Wuhan coronavirus infection: Pathological interrelationship. Indian J Tuberc. 2020;67:264. [CrossRef]

16. World Health Organization. COVID-19: Considerations for tuberculosis (TB) care [Internet]. World Health Organization (WHO) Information Note. 2020 [cited 2020 Jul 27]. p. 1-11. Available from: https://www.who.int/ docs/default-source/documents/tuberculosis/infonotetb-covid-19.pdf

17. Saunders MJ, Wingfield T, Tovar MA et al. A score to predict and stratify risk of tuberculosis in adult contacts of tuberculosis index cases: A prospective derivation and external validation cohort study. Lancet Infect Dis. 2017;17:1190-9. [CrossRef]

18. Saunders MJ, Wingfield T, Datta S et al. A household-level score to predict the risk of tuberculosis among contacts of patients with tuberculosis: a derivation and external validation prospective cohort study. Lancet Infect Dis. 2020;20:110-22. [CrossRef]

19. Covián C, Retamal-díaz A, Bueno SM, Kalergis AM. Could BCG Vaccination Induce Protective Trained Immunity for SARS-CoV-2?. 2020;11:1-7. [CrossRef]

20. Chen T, Dai Z, Mo P, et al. Clinical Characteristics and Outcomes of Older Patients with Coronavirus Disease 2019 (COVID-19) in Wuhan, China: A Single-Centered, Retrospective Study. J Gerontol A Biol Sci Med Sci. 2020;1-8. [CrossRef] 